\title{
A new species of Neosilba (Diptera, Lonchaeidae) from Brazil
}

\author{
Pedro C. Strikis ${ }^{1} \&$ Maria Laura M. Lerena ${ }^{2}$
}

1. Departamento de Parasitologia, Instituto de Biologia, Universidade Estadual de Campinas, Cidade Universitária Prof. Zeferino Vaz, Distrito de Barão Geraldo, Campinas, SP, Brasil. (strikis@uol.com.br)

2. Faculdade de Americana, Av. Joaquim Bôer, 733, Jardim Luciene, 13477-360 Americana, SP, Brasil. (mlmisailidis@gmail.com)

\begin{abstract}
A new species of Neosilba McAlpine, 1962, N. pradoi sp. nov., is described and illustrated. This new species was found in the south of Brazil (Rio Grande do Sul and Santa Catarina), in the southeast (State of São Paulo) and center west (State of Mato Grosso do Sul). It has been reared from fruits of guava (Psidium guajava, Myrtaceae), "araçá" (Psidium cattleyanum, Myrtaceae), "guabiroba" (Campomanesia xanthocarpa, Myrtaceae), Surinam cherry (Malpighia emarginata, Malpighiaceae), cherry (Prunus avium, Rosaceae), orange (Citrus sinensis, Rutaceae), "ingá" (Inga laurina, Fabaceae), "esporão-de-galo" (Celtis iguanae, Ulmaceae) and passion fruit (Passiflora edulis, Passifloraceae).
\end{abstract}

KEYWORDS. Tephritoidea, Lonchaeidae, taxonomy, new species, Neotropical.

RESUMO. Uma nova espécie de Neosilba (Diptera, Lonchaeidae) do Brasil. Uma nova espécie de Neosilba McAlpine, 1962 , N. pradoi sp. nov., é descrita e ilustrada. Esta nova espécie foi encontrada no sul do Brasil (Rio Grande do Sul e Santa Catarina), no sudeste (Estado de São Paulo) e na região centro-oeste (Estado do Mato Grosso do Sul). Foi obtida de frutos de goiaba (Psidium guajava, Myrtaceae), araçá (Psidium cattleyanum, Myrtaceae), guabiroba (Campomanesia xanthocarpa, Myrtaceae), acerola (Malpighia emarginata, Malpighiaceae), cereja (Prunus avium, Rosaceae), laranja (Citrus sinensis, Rutaceae), ingá (Inga laurina, Fabaceae), esporão-de-galo (Celtis iguanae, Ulmaceae) e maracujá (Passiflora edulis, Passifloraceae).

PALAVRAS-CHAVE. Tephritoidea, Lonchaeidae, taxonomia, espécie nova, Neotropical.

Neosilba McAlpine, 1962 comprises 17 described species (STRIKIS \& Prado, 2008) and, at least, others 60 still remain to be described (McAlpine \& Steyskal, 1982). The species in this genus form cryptic complexes (McAlpine \& Steyskal, 1982; Strikis \& PrADO, 2005), what makes it difficult to deal with. Some of its species like, $N$. zadolicha McAlpine \& Steyskal,1982, N. pendula (Bezzi, 1919), N. perezi (Romero \& Ruppel, 1973) and N. bella Strikis \& Prado, 2008 are of economic importance because of the damages they cause in fruit crops and cassava plantations (Lourenção et al. 1996; ARAúJo \& ZuCCHI, 2000; UchôA- Fernandes et al. 2003; Strikis \& Prado, 2008).

Samples of Lonchaeidae flies from many places of Brazil and Latin America are usually received in our laboratory at the Departamento de Biologia Animal, Instituto de Biologia, Universidade Estadual de Campinas, Campinas in order to be identified. Before identification, the specimens are clarified in $10 \% \mathrm{NaOH}$ solution at room temperature for $24 \mathrm{~h}$, then the male and female terminalias are removed under stereomicroscope, observations and measurements are made using a stereomicroscope and the software Image-Prolite version 4.0 for Windows 95/NT/98.

Institutions cited: Museu de Zoologia da Universidade de São Paulo, São Paulo (MZSP) and Museu de Zoologia da Universidade de Campinas, Campinas (ZUEC).

\section{Neosilba pradoi sp. nov.}

(Figs. 1-5)

Etymology. The species name is in honor of Professor Angelo Pires do Prado, a Brazilian entomologist whose contribution to taxonomy is very remarkable.

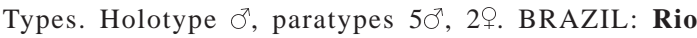
Grande do Sul: Montenegro (29 $36^{\circ} \mathrm{S}$ and $\left.51^{\circ} 31^{\prime} \mathrm{W}\right)$, T. Gattelli col., reared from "araçá" (Psidium cattleyanum, Myrtaceae) (MZSP); 50, 29 from the same sample as the holotype (ZUEC).

Male. Body size $4.53 \mathrm{~mm}$. Head. Frons narrowed toward lunule, wider than long, $1.83 \mathrm{~mm}$ wide and 1.36 $\mathrm{mm}$ long, length/width ratio 0.743 . Lunule with 10 setulae, 5 at each side. Ocellar plate with 5 strong bristles, 2 strong bristles bellow ocellar plate and 4 strong bristles above ocellar plate. Antenna with one prominent bristle in the second segment, first flagelomere $814.64 \mu \mathrm{m}$ long and $200 \mu \mathrm{m}$ wide, length/ width ratio 4.07; arista not densely plumose, longer than first flagelomere, $1 \mathrm{~mm}$ long; arista length/first flagelomere length ratio 1.22. Palpus large and broad. Thorax. Mesonotum with a row of 7 aligned posterior bristles, 6 of which very strong, and 5 anterior bristles. Scutellum with 2 strong apical bristles with 2 setae between it, 2 laterals bristles, one at each side, 6 marginal setae at left side of scutellum and 5 at right side. Dorsum of thorax setulose with 10 strong bristles. Wings. Hyaline, $4.20 \mathrm{~mm}$ long and $1.85 \mathrm{~mm}$ wide, length/ width ratio 2.27 , with yellowish veins and microtrichias; 
calypteres white, with white fringes and a cluster of 4 to 6 setae at fold.

Male terminalia. Small in size, total length of terminalia in lateral view $1.13 \mu \mathrm{m}$ and maximum width $428.07 \mu \mathrm{m}$, length/width ratio 2.65; epandrium short (Fig.1), a little more long than wide, $449.29 \mu \mathrm{m}$ long and $416.41 \mu \mathrm{m}$ wide, length/ width ratio 1.08 , with long hairs at end; in lateral view surstylus is not visible and has 6 prensisetae at each side at its end easily seen in
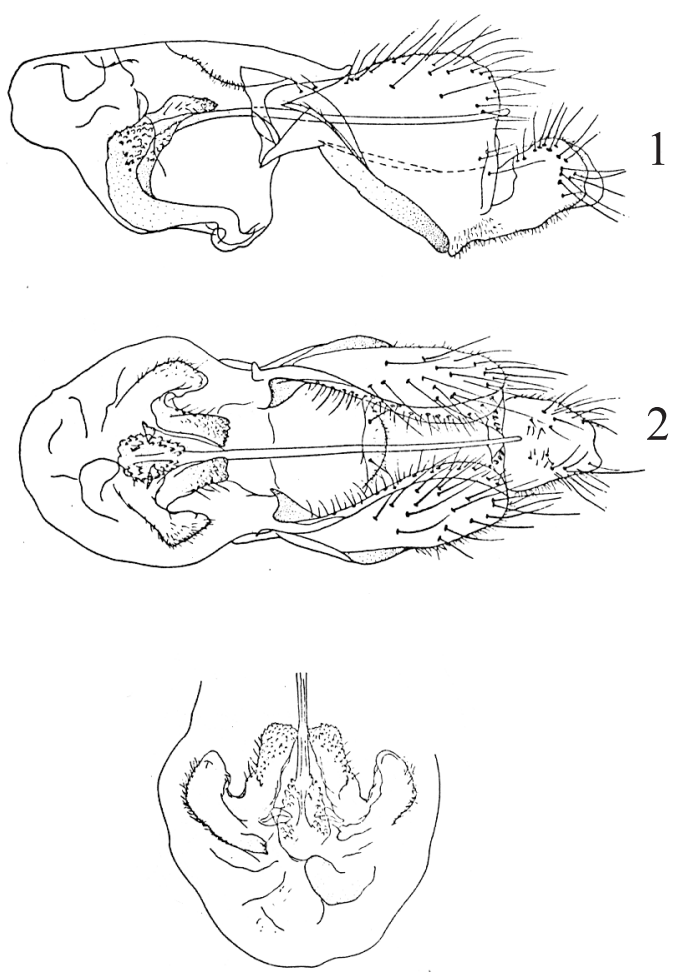

3

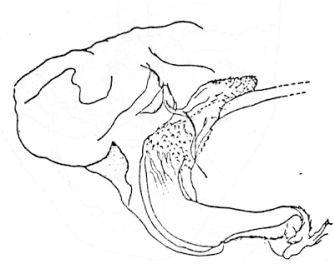

4

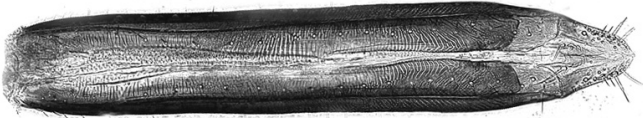

5

Figures 1-5. Neosilba pradoi sp. nov.: 1, male terminalia, lateral view; 2, male terminalia, ventral view; 3 , detail of glomerule like structure, paramere and gonopod, ventral view; 4, detail of posterior end of "C" shaped base of aedeagus showing spicules at its end; 5 , female ovipositor, dorsal view. ventral view (Fig. 2). Paramere lobose with a few setae in ventral view (Fig. 3), gonopod pilose (Fig. 3), aedeagus fine and slender until apex after the "C" shaped base of aedeagus, ending just after surstylus (Figs. 2, 4), posterior end of "C" shaped base of aedeagus with a spiculose glomerule like structure (Fig. 3) very spiculose in lateral view (Fig. 4).

Female. As male except for sexual characters. Ovipositor small, $1.17 \mathrm{~mm}$ long, and very conspicuous at tip, what makes it useful for identification (Fig. 5), because is very different from others species.

Other material examined deposited in the ZUEC: BRAZIL, São Paulo. São Bento do Sapucaí (22\%41'S $\left.45^{\circ} 43^{\prime} \mathrm{W}\right), 50^{\prime}$, 14.IV.1998, A. Raga col., reared from surinam cherry (Malpighia emarginata, Malpighiaceae); São Bento do Sapucaí, 20', 30.IX.1999, M. F. Souza Filho col., reared from cherry (Prunus avium, Rosaceae); Cordeirópolis $\left(22^{\circ} 28^{\prime} \mathrm{S}\right.$, $\left.47^{\circ} 27^{\prime} \mathrm{W}\right), 80^{\circ}, 12 . I I .1985$, P. C. Strikis col., reared from orange (Citrus sinensis, Rutaceae); Mato Grosso do Sul. Campo Grande (20²6'34',S, 54³8'47''W), 10', 26.VI.1999, J. Nicácio col., reared from "ingá" (Inga laurina, Fabaceae); Santa Catarina. Chapecó $\left(27^{\circ} 08^{\prime} \mathrm{S}\right.$ and $\left.52^{\circ} 35^{\prime} \mathrm{W}\right), 30^{\prime}$, 16.XI.1999, F. S. Garcia col., reared from "esporão-de-galo" (Celtis iguanae, Ulmaceae); Chapecó, 307, 20.II.1999, F. S. Garcia col. reared from passion fruit (Passiflora edulis, Passifloraceae); 20, 26.II.2002, F. S. Garcia col., reared from "araçá" (Psidium cattleyanum, Myrtaceae); Rio Grande do Sul. Montenegro (29 $36^{\circ} \mathrm{S}$ and $\left.51^{\circ} 31^{\prime} \mathrm{W}\right), 200^{\circ}$, 28ㅇ, III.2005, T. Gattelli col., reared from "araçá" (Psidium cattleyanum); 30', IV.2005, T. Gattelli col., reared from guava (Psidium guajava, Myrtaceae); 50, IV.2005, T. Gattelli col., reared from "guabiroba" (Campomanesia xanthocarpa, Myrtaceae).

Diagnosis and taxonomic discussion. Paramere shape and the spiculose glomerule-like structure at the end of " $C$ " shaped base of aedeagus are the most distinctive features of $N$. pradoi sp. nov.

Neosilba pradoi sp. nov. is morphologically closely related to $N$. bella Strikis \& Prado, 2008 and to N. bifida Strikis \& Prado, 2005, forming another complex of cryptic species in the genus Neosilba. These species can only be surely separated through the analysis of male genitalia.

Acknowledgments. We thank Dr. Adalton Raga and Dr. Miguel Francisco de Souza Filho, from Instituto Biológico de São Paulo, Dr. Flávio S. Garcia from Universidade Estadual de Santa Catarina, Lages, Dr. Manoel Araécio Uchôa-Fernandes and M. Sc. José Nicácio from, Universidade Federal da Grande Dourados, Dourados, and M. Sc. Tacimara Galletti, from Universidade do Rio dos Sinos for sending us the specimens.

\section{REFERENCES}

Araújo, E. L. \& Zucchi, R. A. 2000. Hospedeiros e níveis de infestação de Neosilba pendula (Bezzi) (Diptera: Lonchaeidae) na região de Mossoró-Açu, R. N. Arquivos do Instituto Biológico 69(2):91-94.

Lourenção, A. L.; Lorenzi, J. O. \& Ambrosano, G. M. B. 1996. Comportamento de clones de mandioca em relação à infestação por Neosilba perezi (Romero \& Rupell) (Diptera: Lonchaeidae). Scientia Agricola 53:304-308.

McAlpine, J. F. \& Steyskal, G. C. 1982. A Revision of Neosilba McAlpine with a Key to World Genera of Lonchaeidae (Diptera). Canadian Entomologist 114:105-137. 
Strikis, P. C. \& Prado, A. P. 2005. A new species of genus Neosilba (Diptera: Lonchaeidae). Zootaxa 828:1-5.

_-_. 2008. Neosilba (Tephritoidea: Lonchaeidae) Species reared from coffee in Brazil, with description of a new species. In: International Symposium on Fruit Flies of Economic Importance: From Basic to Applied Knowledge. $7^{\circ}$, Salvador, 2006, Proceedings... Juazeiro. MOSCAMED. p. 187-193.

Uchôa-Fernandes, M. A.; Oliveira, I.; Molina, R. M. S. \& Zucchi, R. A. 2003. Biodiversity of frugivorous flies (Diptera: Tephritoidea) captured in citrus groves, Mato Grosso do Sul, Brazil. Neotropical Entomology 32(2):239-246.

Recebido em abril de 2007. Aceito em maio de 2009. ISSN 0073-4721 Artigo disponível em: www.scielo.br/isz 